\title{
Effect of Growth Regulators on Growth and Yield of Turmeric var. Suroma
}

\author{
Ravi Pujari*, Shankargouda Patil, Ajithkumar. S, Sunanda, B. Babaleshwar, \\ Sashidhar, M. Dodamani and M.R. Shivanand \\ Department of Plantation, Spices, Medicinal and Aromatic crops, KRC College of \\ Horticulture, Arabhavi, University of Horticultural Sciences, Bagalkot, \\ Karnataka-591 218, India \\ *Corresponding author
}

\begin{abstract}
A B S T R A C T
Keywords

Growth regulators,

Turmeric rhizome

sizes, Growth and

yield attributes

Article Info

Accepted:

26 December 2017

Available Online:

10 January 2018

An experiment was conducted to find out the effect of different growth regulators on growth and yield of turmeric, with four treatments replicated three times. Among the different treatments evaluated for growth and yield of turmeric, the treatment $\mathrm{G}_{3}$ (NAA 20 ppm) recorded maximum $(80.84 \mathrm{~cm})$ plant height, number of leaves per tiller $(26.32)$, leaf area $\left(288.38 \mathrm{~cm}^{2}\right)$, number of tillers per clump (5.63), harvest index $(88.01 \%)$, number of rhizomes per clump (31.03), diameter of rhizome clump (29.02 mm), clump size (42.37 $\left.\mathrm{cm}^{2}\right)$, yield per clump (295.41g), yield per plot $(8.08 \mathrm{~kg})$ and yield per hectare $(18.08 \mathrm{t} / \mathrm{ha})$ at $180 \mathrm{DAP}$ and the treatment $\mathrm{G}_{1}($ Cycocel $1000 \mathrm{ppm})$ recorded least $(65.60 \mathrm{~cm})$ plant height, number of leaves per tiller (19.04), leaf area $\left(190.01 \mathrm{~cm}^{2}\right)$, number of tillers per clump (4.40), number of rhizomes per clump (23.61), diameter of rhizome clump (22.67 $\mathrm{mm})$, clump size $\left(28.79 \mathrm{~cm}^{2}\right)$, yield per clump $(214.26 \mathrm{~g})$, yield per plot $(4.24 \mathrm{~kg})$ and yield per hectare $(10.77 \mathrm{t} / \mathrm{ha})$ but the harvest index was lowest $(73.52 \%)$ in $\mathrm{G} 4$ (Control) at $180 \mathrm{DAP}$.
\end{abstract}

\section{Introduction}

Turmeric (Curcuma longa L.) is an important, sacred and ancient spice of India. It is a major rhizomatous spice produced and exported from India.

Turmeric is an herbaceous perennial plant, native to tropical South-East Asia, belonging to the family Zingiberaceae, under the order scitaminae. It is cultivated for its underground rhizomes which is used as spice and condiment, dye stuff and in cosmetic and drug industry, particularly in the preparation of anticancerous medicines. India is the world's largest producer and exporter of turmeric and it produces nearly 50 per cent of global turmeric production. It is grown in an area of 1.92 lakh hectares with an average production of 8.93 lakh MT (Anonymous, 2012).

The cost of planting material amounts to $50 \%$ of crop production in turmeric. Studies on the use of different growth regulators are scanty. Hence there is a need to study the effect of different growth regulators to know the best suited growth regulator for getting higher yields under field condition. 


\section{Materials and Methods}

The study was carried out in the field of Plantation, Spices, Medicinal and Aromatic Crops of Kittur Rani Chennamma College of Horticulture Arabhavi during May of 20122013. There were three treatments $\mathrm{G}_{1}$ (Cycocel 1000ppm), G G $_{2}$ (6- BA 5 ppm), G 3 (NAA 20 $\mathrm{ppm})$ and $\mathrm{G}_{4}$ (Control) were used for the experiment.

The field trial was laid out in RBD and was replicated three times at spacing of $45 \mathrm{~cm}$ between rows and $22.5 \mathrm{~cm}$ between the plants (ridge and furrow method) was followed, accommodating 98,765 plants per hectare. Observations on growth parameters were recorded on five randomly selected clumps in each treatment at monthly intervals starting from 30 days after planting (DAP) till harvest i.e. upto 180 days after planting (DAP).

\section{Results and Discussion}

Experimental results indicated that the treatment $\mathrm{G}_{3}$ (NAA $20 \mathrm{ppm}$ ) recorded maximum $(80.84 \mathrm{~cm})$ plant height, number of leaves per tiller (26.32), leaf area $\left(288.38 \mathrm{~cm}^{2}\right)$, number of tillers per clump (5.63), harvest index $(88.01 \%)$, number of rhizomes per clump (31.03), diameter of rhizome clump
(29.02 mm), clump size $\left(42.37 \mathrm{~cm}^{2}\right)$, yield per clump (295.41g), yield per plot $(8.08 \mathrm{~kg})$ and yield per hectare $(18.08 \mathrm{t} / \mathrm{ha})$ at $180 \mathrm{DAP}$ and the treatment $\mathrm{G}_{1}$ (Cycocel $\left.1000 \mathrm{ppm}\right)$ recorded least $(65.60 \mathrm{~cm})$ plant height, number of leaves per tiller (19.04), leaf area (190.01 $\mathrm{cm}^{2}$ ), number of tillers per clump (4.40), number of rhizomes per clump (23.61), diameter of rhizome clump (22.67 $\mathrm{mm})$, clump size $\left(28.79 \mathrm{~cm}^{2}\right)$, yield per clump $(214.26 \mathrm{~g})$, yield per plot $(4.24 \mathrm{~kg})$ and yield per hectare $(10.77 \mathrm{t} / \mathrm{ha})$ but the harvest index was lowest (73.52 \%) in G4 (Control) at 180 DAP. But he pseudo stem growth was found to be non-significant.

Growth attributes such as plant height, pseudostem girth, number of leaves per tiller, leaf area, number of tillers per clump, harvest index, number of rhizomes per clump, diameter of rhizome clump, clump size, yield parameters were highest in treatment $\mathrm{G}_{3}$ (NAA $20 \mathrm{ppm}$ ) which may be attributed to the formative effect of cell elongation and cell division. The result of present study is in conformity with results of (Dhanoji, 2010) and (Sengupta et al., 2008) who recorded similar results with respect to the effects of growth regulators on vegetative parameters in ginger (Table 1 and 2).

Table.1 Effect of growth regulators on the plant height, pseudo stem girth, number of leaves per tiller, leaf area, number of tillers per clump and harvest index in turmeric var. Suroma

\begin{tabular}{|c|c|c|c|c|c|c|}
\hline Treatment & $\begin{array}{c}\text { Plant } \\
\text { height }(\mathrm{cm})\end{array}$ & $\begin{array}{l}\text { Pseudo stem } \\
\text { girth (mm) }\end{array}$ & $\begin{array}{c}\begin{array}{c}\text { No. of } \\
\text { leaves per }\end{array} \\
\text { plant }\end{array}$ & $\begin{array}{c}\text { Leaf area } \\
\left(\mathrm{cm}^{2}\right)\end{array}$ & $\begin{array}{l}\text { No. of } \\
\text { tillers/ } \\
\text { clump } \\
\end{array}$ & $\begin{array}{c}\text { Harvest } \\
\text { index }(\%)\end{array}$ \\
\hline $\begin{array}{c}\mathrm{G}_{1}: \text { Cycocel } \\
1000 \text { ppm }\end{array}$ & 65.60 & 6.67 & 19.04 & 190.01 & 4.40 & 75.16 \\
\hline $\begin{array}{c}\mathrm{G}_{2}: \text { 6- BA } 5 \\
\text { ppm }\end{array}$ & 73.59 & 7.12 & 21.04 & 212.82 & 4.06 & 76.92 \\
\hline $\begin{array}{c}\mathbf{G}_{3}: \text { NAA } 20 \\
\text { ppm }\end{array}$ & 80.84 & 7.09 & 26.32 & 288.38 & 5.63 & 88.01 \\
\hline $\mathbf{G}_{4}:$ Control & 67.73 & 6.72 & 21.04 & 202.72 & 4.65 & 73.52 \\
\hline S.Em \pm & 1.36 & 0.11 & 0.33 & 4.19 & 0.13 & 1.48 \\
\hline CD@ $5 \%$ & 4.61 & NS & 1.126 & 14.203 & 0.44 & 5.03 \\
\hline
\end{tabular}


Table.2 Effect of types of rhizome sizes on the number of rhizomes per clump, diameter of rhizome per clump, clump size, yield per clump, yield per plot and yield per hectare in turmeric var. Suroma

\begin{tabular}{|c|c|c|c|c|c|c|}
\hline Treatment & $\begin{array}{l}\text { Number of } \\
\text { rhizomes } \\
\text { per clump }\end{array}$ & $\begin{array}{l}\text { Diameter of } \\
\text { rhizome clump } \\
(\mathbf{m m})\end{array}$ & $\begin{array}{l}\text { Clump size } \\
\left(\mathrm{cm}^{2}\right)\end{array}$ & $\begin{array}{l}\text { Yield } \\
\text { (g/clump) }\end{array}$ & $\begin{array}{l}\text { Yield } \\
\text { (kg/plot) }\end{array}$ & $\begin{array}{l}\text { Yield } \\
\text { (tons/ ha) }\end{array}$ \\
\hline $\begin{array}{c}\mathrm{G}_{1}: \text { Cycocel } \\
1000 \text { ppm }\end{array}$ & 23.61 & 22.67 & 28.79 & 214.26 & 4.24 & 10.77 \\
\hline $\begin{array}{c}\mathrm{G}_{2}: \mathbf{6 - B A} 5 \\
\text { ppm }\end{array}$ & 27.25 & 25.73 & 36.16 & 222.13 & 5.99 & 14.13 \\
\hline $\begin{array}{c}\mathbf{G}_{3}: \text { NAA } 20 \\
\text { ppm }\end{array}$ & 31.03 & 29.02 & 42.37 & 295.41 & 8.08 & 18.08 \\
\hline $\mathbf{G}_{4}:$ Control & 23.68 & 23.33 & 37.23 & 219.77 & 5.36 & 13.44 \\
\hline S.Em \pm & 0.46 & 0.45 & 0.66 & 9.00 & 0.27 & 0.35 \\
\hline CD@5\% & 1.55 & 1.53 & 2.23 & 30.49 & 0.92 & 1.17 \\
\hline
\end{tabular}

Growth regulator, NAA 20 ppm which influenced fresh rhizome yield and yield attributes significantly, may be attributed to its formative effect on cell elongation, cell division and better vegetative growth in terms of plant height, number of leaves and leaf area, which might have influenced the production of more number of rhizomes, diameter and size of clump, finally leading to increase in fresh rhizome yield in turmeric. Synthesis of more photosynthates due to better growth and translocation into sink might have resulted in better yield of rhizomes. The results obtained in present investigation are in conformity with the reports of Jirali et al., (2008), Balwinder and Gill (2010) and Obasi and Atanu (2005).

\section{References}

Anonymous, 2012. Indian Horticulture Database, National Horticulture Board. Pp. 6.

Balwinder, K., and Gill BS 2010. Growth, yield and quality of turmeric (Curcuma longa L.) as influenced by planting method, plant density and planting material. J. Spices and Aromatic Crop. 19(1 \& 2): 42-49.

Dhanoji, M.M., 2010. Effect of foliar spray of micronutrients and plant growth regulators on growth and yield of turmeric (Curcuma longa L.). Asian J. of Hort., 5 (2): 503-505.

Jirali, D.I., Hiremath SM, Patil SA 2008. Studies on yield component, yield and quality as affected by growth regulators on turmeric. J. of Eco-friendly Agri., 3(2): 119-122.

Obasi, O.M., and Atanu SO 2005. Effect of growth regulators on growth, flowering and rhizome yield of ginger (Zingiber officinale Rosc). Nigerian J. of Horti. Sci., 9: 69-73.

Sengupta, D.K., Maity TK, Som MG, Bose TK 2008. Effect of growth regulators on growth and rhizome production of ginger in hilly region of Darjeeling district. J. of Crop and Weed, 4 (2): 10-13.

\section{How to cite this article:}

Ravi Pujari, Shankargouda Patil, Ajithkumar. S, Sunanda, B. Babaleshwar, Sashidhar, M. Dodamani and Shivanand, M.R. 2018. Effect of Growth Regulators on Growth and Yield of Turmeric var. Suroma. Int.J.Curr.Microbiol.App.Sci. 7(01): 3156-3158. doi: https://doi.org/10.20546/ijcmas.2018.701.374 